\title{
Periodism of Chinese Current Account Surplus
}

\author{
Ping $\operatorname{Han}^{1}$ \\ ${ }^{1}$ School of Economics and Finance, Shandong Jiaotong University, Jinan, Shandong, China \\ Correspondence: Ping Han, School of Economics and Finance, Shandong Jiaotong University, Jinan, Shandong, \\ China. E-mail: vhanping@126.com \\ Received: December 1, 2014 \\ Accepted: January 3, 2015 \\ Online Published: January 22, 2015 \\ doi:10.5430/bmr.v4n1p44 \\ URL: http://dx.doi.org/10.5430/bmr.v4n1p44
}

\begin{abstract}
By using relevant theories of balance of payments, this paper discusses periodic change of Chinese current account balance and put forward some countermeasures to improve current account surplus.
\end{abstract}

Keywords: Current account balance, Trade balance, Direct investment, RMB exchange rate

\section{The current account surplus}

Since 1994 China's current account has remained surplus. The surplus value increased from $\$ 6.91$ billion in 1994 to $\$ 259.75$ billion in 2013. The percentage of current account surplus to GDP increased from $1.4 \%$ to $3.1 \%$. Factors that affect China's current account surplus mainly include the following.

\subsection{Trade balance}

From 1982 to 1996, Chinese government does not report current account balance. We can use imports and exports of goods to substitute current account balance in this period. It can be seen that the current account balance and the trade balance moved together. Before 1993, trade balance and the current account balance were small in number, surplus and deficit appeared alternately. Because this time is the early stage of reform and opening up, merchandise exports have just started. At the same time, demand for foreign advanced technique and technology driven the growth of imports. During this period, the instability of international political and economic environment increased the volatility of our country's current account. And since the mid 1990s, current account balance started to go to surplus, but the surplus value hasn't changed so much.

In the 1990s, the world economy and Chinese economy began to grow rapidly; both import and export growth is strong. In 2003, a sharp increase in surplus start and current account surplus is greater than the trade surplus. The difference between current account balance and trade balance gradually increased. On the one hand, this is because Chinese export commodities in the world market has a strong competitiveness which increased export; On the other hand, this is because the participate form of china in the international trade improved gradually, other forms of transaction except merchandise import and export also developed.

\section{2 investment - saving}

For a long time, China's economy is mainly characterized by high deposit, high investment and low consumption, and the savings rate is higher than the rate of investment for a long time. In 2007, for example, China's savings rate is $50.88 \%$, the investment rate is $41.73 \%$, a level not only higher than the average level of developed countries, but also higher than the level of developing countries.

The underlying reason of high savings is China's existing institutional defects. For individuals, expensive housing, rising cost of education, imperfect of pension, medical, social security system lead to increase in precautionary saving; For enterprises, due to the imperfect financial system, some non-state enterprises and small and medium-sized enterprise are hard to obtain capital through financing market, most of them can only rely on their own retained earnings to support their development which caused their saving rate increased. High savings crowded out consume, also caused high investment. Investment increase will definitely cause the increase of output. Under the situation of low domestic consumption, excess production caused by high investment can only release through exports, which led to a widening trade surplus.

Statistically, investment-saving gap is in the same tendency with Chinese current account surplus. From 1982 to 1996, both of them are small. From 1997 to 2001, they all decreased a lot; from 2002 to 2007, they increase slowly at 
first and then got a sharp increase in 2005. The increase continued until 2007. In 2008, investment-saving gap decreased, current account surplus increased, but its growth rate is obviously slow.

\subsection{The foreign direct investment(FDI)}

FDI influence current account balance in two ways:

On the one hand, FDI influence trade balance. FDI have both direct and indirect effect on host countries. Direct effect refers to the influence of import, export of foreign enterprises themselves on exports, imports, the net exports of host countries. According to the types, FDI can be divided into export-oriented one and market-oriented one. They have different effects on trade balance. Export-oriented foreign investments combine their advanced technology, overseas sales channels and strong marketing skills with the cheap raw materials and labor in host countries. Cost can be reduced and international competitiveness improved. Also, exports of host countries can be promoted, trade surplus in host countries increased.

FDI incomes can also influence current account balance. Incomes of foreign direct investment generally go two ways: one is remit back to home countries; the other is reinvest in host countries (which is direct investment in capital account). No matter the current usage of incomes, it will finally be remitted back to home countries. The re-investment is just delay the remittance. The delay of income remittance may lead to concentrated remittance in the future, which may cause pressure on current account.

At the beginning of the reform and opening up, due to the shortage of foreign exchange, China introduced a series of preferential policies to attract foreign direct investment. This is because the FDI as a kind of long-term investment, the pressure of repayment will not occur in short-medium term. In the short-run FDI is helpful in the introduction of foreign advanced technology and management experience.

\section{Periodism of Chinese current account surplus}

2.1 Chinese current account surplus

Table 2-1 Chinese current account balance from 1982 to 2013

Unit: Billion USD

\begin{tabular}{cccccccc}
\hline year & balance & year & balance & year & balance & year & balance \\
\hline 1982 & 56.74 & 1989 & -43.18 & 1996 & 72.42 & 2003 & 458.75 \\
1983 & 42.4 & 1990 & 119.97 & 1997 & 369.63 & 2004 & 686.59 \\
1984 & 20.3 & 1991 & 132.71 & 1998 & 314.71 & 2005 & 1608.18 \\
1985 & -114.17 & 1992 & 64.01 & 1999 & 211.14 & 2006 & 2532.68 \\
1986 & -70.35 & 1993 & -119.04 & 2000 & 205.19 & 2007 & 3718.33 \\
1987 & 3 & 1994 & 76.58 & 2001 & 174.05 & 2008 & 4261.07 \\
1988 & -38.03 & 1995 & 16.18 & 2002 & 354.22 & 2009 & 2971 \\
2010 & 2378 & 2011 & 1361 & 2012 & 2154 & 2013 & 2597.5 \\
\hline
\end{tabular}

Since 1982, China began to sum the remaining of balance of payments. We can see from table 2-1, in year 1985 , 1986, 1988, 1989 and 1993, Chinese current account balances are deficit. In the rest of time, current account balances are surplus. Changes of current account balance from 1982 to 2009 can be divided into four periods.

The first period is from 1982 to 1984. In these three years, China's current account balance is small in surplus with gradually decreasing trend. This is largely because china has just implement reform and opening up policy. Domestic demand for foreign advanced technology led to the increase in imports.

The second period is from 1985 to 1989. Current account balances are mostly deficit during this period. There only existed a small surplus in 1987. Import is still prominent in this period.

The third stage is from 1990 to 2000 . During this period, the current account balances are surplus except a deficit in 1993. This is mainly due to our export promotion policy. The policy greatly mobilized the enthusiasm of foreign trade enterprises and promoted the development of export. The violation of international political and economic environment contributed to the fluctuation of current account surplus. 
The fourth period is from 2001 to 2013. The current account surplus increased rapidly. Surplus increased 23 times. But affected by the world economic crisis of 2008, the surplus growth declined in 2009.

\subsection{Periodism of Chinese current account surplus}

\subsubsection{Merchandise}

From1997 to 2009, merchandise surplus changed in step with current-account surplus. Before 2002, the overall amplitude is not large, fluctuated within $\$ 300$ - $\$ 50$ billion. Starting from 2003, trade surplus and current-account surplus grow rapidly which increase to the a peak in 2008. surplus decreased in 2009. In addition, the merchandise surplus accounted for more than $80 \%$ of the current account surplus, which made it a major cause of current account surplus.

From the current way of Chinese commodity import and export, processing trade is a component of transactions.

\subsubsection{Service}

Services continued deficit from 1997 to 2009, in which transportation, insurance services, and exclusive rights fee are primary source of deficit. Tourism and other business services is the main source of surplus. Construction, computer, information and consultation services gradually changed from deficit to surplus.

Transportation and tourism has been major components of Chinese service transaction, but the proportion of them is declining slowly. In 2009 , the two accounted for $53 \%$ of the total scale of service transaction which fell about $1 \%$ comparing with former year. At the same time, the proportion of building services, exclusive rights fee, and royalty, computer and information services increased slightly. This shows that structure of Chinese service is improving. The increased service deficit tells that service is still lack of comparative advantage at present.

\subsubsection{Incomes}

Current account incomes continued deficit from 1997 to 2004. During this period, incomes deficit accounts for 30\% of trade surplus, even more than $50 \%$ in 2001 . This shows that $1 / 3$ of trade incomes was offset by payment to foreign investors. After 2005, incomes began to go to surplus. The surplus came from profit of foreign exchange reserves and foreign direct investment. It was also brought by foreigners, re-investment. For the latter situation, we should know that foreign direct investment is essentially a way of financing and should be repaid in the future. Reinvestment of profit did not change the fact that capital inflows will definitely outflow some days. It was just delayed remittance and will be concentrated in the future.

\subsubsection{Unilateral transfer}

China has always been net recipients of transfer, and the surplus also showed a trend of widening. In 2009, the surplus has reached to $\$ 33.7$ billion. but unilateral transfer account for about $11 \%$ of current account surplus. Foreign remittance of Chinese residents is the main source of unilateral transfer surplus.

\section{Suggestions on improvement of current account surplus}

\subsection{Strengthen macroeconomic regulation}

The government's properly macroeconomic control is very important in stabilizing domestic economy and promoting steady development of current account. The government should continue to strengthen macroeconomic regulation and control. Adhere to the market economy reform. At the same time, the government should properly deal with relationship between short-term and long-term.

\subsection{Improve foreign trade policy}

\subsubsection{Encourage imports and promote trade balance}

Exports should be reduced and imports should be increased in order to realize trade balance. Under the current situation, government should continue to insist stable of export. On the other hand, import should be encouraged and increased. Imports can introduce advanced technology and equipment, improve competitiveness of domestic production. Also, optimal allocation of resources can be achieved; driving conversion of the capital to productivity, improving product efficiency and technical level.

\subsubsection{Stable RMB exchange rate}

To keep the RMB exchange rate at a reasonable and balanced level, macroeconomic and financial market should be stabilized. It is necessary to further promote the reform of RMB exchange rate formation mechanism, increase the elasticity of the RMB exchange rate. In the process of the reform of the RMB exchange rate, managed floating exchange rate system based on market supply and demand should with reference to a basket of currencies should be 
stick to.

At the same time, attention should be paid to improve the occasional disadvantages, and strive to minimize negative impacts. One is to make sure that exchange rate volatility controllability, thus preventing the possibility of the RMB exchange rate overshoot caused by market forces. Two is to make RMB exchange rate floating in accordance with China's economic fundamentals and the needs of the macroeconomic regulation. Three is manage and regulate in a gradual way in order to set aside for the enterprise structure adjustment. This can help to orderly industry upgrading, to maintain the overall competitiveness of China's enterprises in the international market. Four is to strengthen monitoring and management of short-term speculative capital, mass flow to prevent hot money cause serious impact to the domestic financial system.

\subsection{Domestic policy}

\subsubsection{Decrease savings rate and increase consumption}

Known as the tradition of high savings in China, coupled with the system transition of the social security system has not yet fully completed. Precautionary savings of residents used as pension, health care and education is high. This increased the residents' savings. At the same time, relatively lag of financial system blocked transfer of domestic savings into investment. Firms have to rely on their own savings, and these factors caused a gap between saving and investment. To change the situation, promote trade balance, government should promote development of social security system and financial system.

\subsubsection{Perfect the policy of using foreign capital, improve the quality of foreign capital usage}

China's local governments had their own policies of attracting foreign investment in order to develop local economy. The continuing growth of FDI has brought China advanced technology, more employment channels. FDI played an important role in the development of national economy. No doubt, to attract foreign investment in the future will still be a basic national policy. But it is not good for fair competition between foreign enterprises and domestic companies by mainly rely on preferential policies to attract foreign investment. From a long-term point of view, it is often not continuous. Entering into the new century, the focus of FDI changed from cheap labor, natural resources advantage to technical level, national quality, the domestic market capacity and environmental factors such as macroeconomic conditions and infrastructure. industrial cluster began to attract multinational companies strongly. Accordingly, the government should formulate the reasonable industry preferential policy, determining the direction of the reform and reorganization industrial structure in introducing foreign capital, objectives, steps and keys. FDI should be led to agriculture, energy, transportation, and important basic industries such as raw material production and construction department in a planned way. Environment and industrial cluster should be focus on. Advantages of regional resources and industry should be developed, in order to improve domestic enterprises ability of the supply and demand.

\section{References}

He bingxin, zhang bin. (2006). From high foreign exchange reserves to reflect on the internal and external imbalance of China's economic development. Journal of international economic review, 2006, (3).

Jian qingzhang, etc. (2007). The global current account imbalances study. Journal of world economic studies, 2007, (1).

Jiang boke. (2008). International finance. 4th edition, Shanghai: fudan university press.

Li ping he. (2004). From two angles analysis of China's international balance of payments structure. China's foreign exchange management, 2004, (4).

Wang xin. (2004). China's current-account surplus can be sustained. Journal of international financial research, 2004, (1).

Wang xin. (2006). From the international perspective of China how to adjust current account imbalances. Journal of international economic review, 2006, (5).

Xiao hongmeng. (2004). The analysis of the dynamic relationship of current account and capital account. Journal of quantitative technical economics, 2004, (9).

Yang liuyong. (2003). The balance of payments structure research. Beijing: China financial publishing house.

Zhao fu. (2006). World economic structural changes and the current account imbalances. Journal of international financial research, 2006, (4). 